Dept. of Clinical Studies,

College of Vetrinary Medicine and Animal Resources,

King Faisal University, KSA.

\title{
CLINICAL OBSERVATIONS AND SIGNIFICANCE OF BHV-1 INFECTION IN SMALLHOLDERS OF CATTLE IN AL-AHSA REGION, KSA
}

(With 4 Tables)

By

F.M.T. HOUSAWI; A. AL-NAEEM; E.M.E. ABU-ELZEIN;

A. AFALEQ and A.A. ZAGHAW

(Received at 15/9/2010)

ملاحظات اكلينيكية وأهمية العدوي بفيروس الهربس البقري-1 في الأبقار في

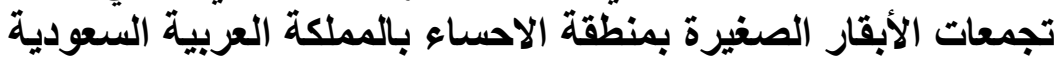

فاضل محد هوساوي ، عبل المحسن النعيم ، الطبب ابو الزين ، عادل العفالق ،

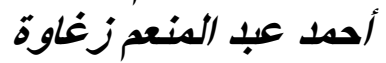

يعتبر فيروس الهربي البقري- 1 المصنف بعائلة فيروسات الهربس من اخطر الأمر اض التي التي الئي

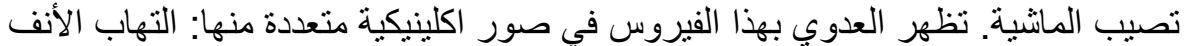

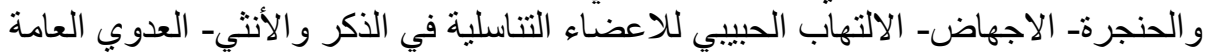

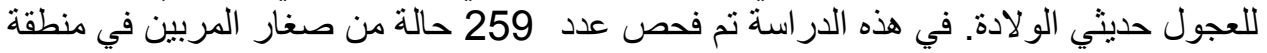
الاحساء بالمملكة العربية السعودية في الفترة من ابرة العريل

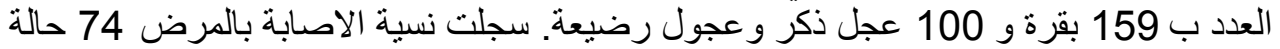

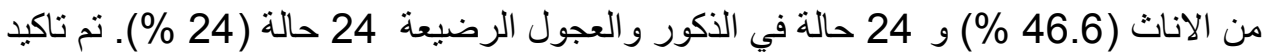

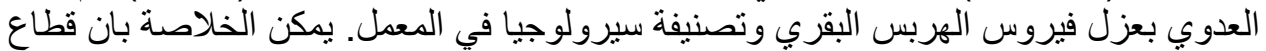

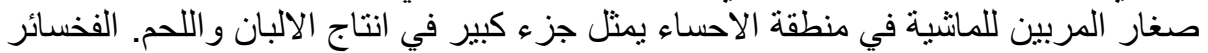

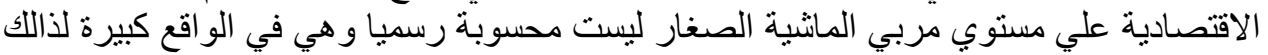

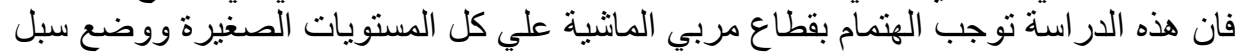

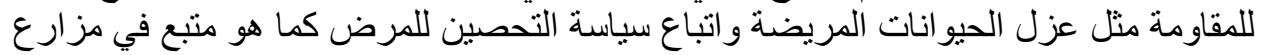

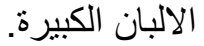

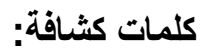
(فيروس الهربس البقري- 1 و الأعر اض الاكلينيكية وصغار مربيالماثية وعزل وتصنيف

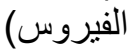

\section{SUMMARY}


Bovine herpesvirus 1 (BoHV-1), classified as an alphaherpesvirus, is a major pathogen of cattle. Primary infection is accompanied by various clinical manifestations such as infectious bovine rhinotracheitis, abortion, infectious pustular vulvovaginitis, and systemic infection in neonates. In this study A total of 259 animal in small holder cattle sector in Al-Ahsa region, KSA were under investigation form April, 2007 till April 2010. The total number of observed cattle was 259 (159 females and 100 males). The clinical signs of the disease was observed in $74(46.6 \%)$ females and 24 (24\%) males. The clinical symptoms are described in both male and female animals as well as young calves. BHV-1 infection was confirmed by isolation and serological identification of the virus. It can be concluded that the sector of smallholders cattle breeding constitutes an important part for cattle production on both dairy and beef cattle in Kingdom Saudi Arabia. The economic losses in this sector due to infectious diseases are really high but unfortunately not estimated. BHV-1 infection in cattle is one of the problems that threads and persist in small holders cattle causing sever economic losses and constitutes a major source of infection to industrial cattle farms. This is probably due to the absence of application of control program for infectious diseases as for example regular vaccination and isolation of infected animals.

Key words: BHV-1, clinical observation, small holder, virus isolation)

\section{INTRODUCTION}

Bovine herpesvirus 1 (BoHV-1), classified as an alphaherpesvirus, is a major pathogen of cattle. Primary infection is accompanied by various clinical manifestations such as infectious bovine rhinotracheitis, abortion, infectious pustular vulvovaginitis, and systemic infection in neonates (Muyalkens et al., 2007; Nandi et al., 2009). All BoHV-1 strains isolated hitherto belong to one single viral species, and are classified in three subtypes BoHV-1.1, BoHV-1.2a and BoHV-1.2b. Although most BoHV1.1 strains have been isolated from respiratory tract diseases or abortive cases and BoHV-1.2 strains from genital organ lesions, the only reliable distinctive criterion is the viral DNA analysis by restriction endonuclease fingerprinting (Edward et al.,1991; Metzler et al., 1985; Miller et al., 1991). Calves infected experimentally by the nasal route with BoHV-1.2 strains showed respiratory clinical signs (Engels et al., 1981; Spilki et al., 2004) and were able to transmit the respiratory infection to control calves (Smith et al., 1980; Edwards et al., 1991). Otherwise, reproductive tract 
lesions in heifers were observed after intrauterine inoculation with BoHV1.1 (Miller and Van der Maaten 1984). Subtypes 1.1 and 1.2a have been associated with severe diseases including infection of the fetus and abortion (Miller et al., 1991). The subtype 1.2b was not associated with abortion (Whetstone and Miller 1989; Edwards et al., 1990; Smith et al., 1995). BoHV-1 is responsible for significant losses incurred by disease and trading restriction in the cattle industry (Bowland and Shewen, 2000). BoHV-1 is one of the eight herpesviruses isolated hitherto from naturally infected cattle (Tab. I). All members of the family Herpesviridae share a common virion morphology based on an icosahedral capsid symmetry, a cell-derived envelope containing virally encoded membrane proteins and a tegument as protein made matrix connecting the capsid and the envelope. BoHV-1 belongs to the extensive subfamily of Alphaherpesvirinae which contains viruses characterized by a relatively large host range, a short replication cycle and the ability to induce latent infection mainly, but not exclusively, in neurons.

Table 1: Herpesviruses isolated from naturally infected cattle after Muyalkens et al. (2007).

\begin{tabular}{|l|c|l|}
\hline \multicolumn{1}{|c|}{ Virus species Disease } & $\begin{array}{c}\text { Herpesvirus } \\
\text { subfamily }\end{array}$ & \multicolumn{1}{|c|}{$\begin{array}{c}\text { Disease following primary } \\
\text { infection }\end{array}$} \\
\hline Cattle as natural host & Alpha & Infectious bovine rhinotracheitis \\
Bovine herpesvirus 1 (BoHV-1) & Alpha & $\begin{array}{l}\text { Bovine mammillitis } \\
\text { Pseudo lumpy skin disease }\end{array}$ \\
Bovine herpesvirus 4 (BoHV-4) & Gamma & Not determined \\
Bovine herpesvirus 5 (BoHV-5) & Alpha & Bovine herpesvirus encephalitis \\
Bovine lymphotrophic herpesvirus & Gamma & Not determined \\
(BLHV) & & \\
\hline Cattle as foreign host & Gamma & Malignant catarrhal fever \\
Alcelaphine herpesvirus 1 (AlHV-1) & Gamma & \\
Ovine herpesvirus 2 (OHV-2) & Alpha & Aujeszky's disease \\
Suid herpesvirus 1 (SuHV-1) & &
\end{tabular}

Bovine herpesvirus 5 (BoHV-5) is an alphaherpesvirus responsible for meningoencephalitis in young cattle and is closely antigenically and genetically related to bovine herpesvirus 1 (BoHV-1). Both viruses have common aspects in their pathogenesis: (1) they infect epithelial cells at the 
portal of entry and (2) they establish a latent infection in the sensory nerve ganglia, i.e., the trigeminal ganglia (Zajac, et al., 2010). The severity of the disease caused by BoHV-1 is influenced by several factors such as the virulence of the BoHV-1 strain (Kaashoek et al., 1996), resistance factors of the host, especially the age, and potential concurrent bacterial infection. Subclinical BoHV-1 infections are common. Several BoHV-1 strains display a poor ability to induce clinical signs and were classified as weakly virulent strains in a comparative virulence experiment (Kaashoek et al., 1996). Otherwise, these discrete clinical pictures can also be explained by the primary infection of passively immune calves in countries where BoHV-1 is endemic. Indeed, colostral immunity is known to protect efficiently infected animals from clinical signs (Mechor et al., 1987; Lemaire et al., 2000). The latency reactivation cycle of herpesviruses has a deep epidemiological impact since it is responsible for the maintenance of BoHV-1 in a cattle population. BoHV-1 infection of new generation cattle by latent carriers submitted to reactivation stimulus may occur at several occasions as for example at birth (Spilki et al., 2004), mating, during transport (Thiry et al., 1987) or following the introduction of heifers into the group of dairy cows. Therefore the detection of BoHV-1 latent carriers is a concern in the setting up of a BoHV-1 control program.

The sector of smallholders in cattle breeding constitutes an important part for cattle production on both dairy and beef cattle in Kingdom Saudi Arabia. The aim of the present work was planned to fulfill the followings: recording and investigate the clinical observations of BHV1 in smallholders cattle in Al-Ahsa region, KSA, collection of information about current control program in this sector, confirmation of clinical cases through virus isolation and identification, and finally recommendation to control the disease in smallholders cattle in KSA.

\section{MATERIALS and METHODS}

\section{1- Animals:}

The description of the animals is very difficult because they collected from different small system that has irregular management system and there were no confirmed data about any other infection during the period of observation.

A total of 259 animal were under investigation form April, 2007 till April 2010. Details of information are found in the Table (2).

Table 2: Animals under investigation 


\begin{tabular}{|c|c|c|c|}
\hline Year & $\begin{array}{l}\text { Total Animal } \\
\text { examined }\end{array}$ & Sex & Age average \\
\hline 2007 & 24 & $\begin{array}{l}18 \text { males \& } \\
6 \text { female }\end{array}$ & $\begin{array}{l}3 \text { years } \\
3.5 \text { years }\end{array}$ \\
\hline 2009 & 70 & $\begin{array}{l}42 \text { males \& } \\
28 \text { females }\end{array}$ & $\begin{array}{l}3 \text { years } \\
3.5 \text { years }\end{array}$ \\
\hline 2010 & 165 & $\begin{array}{l}99 \text { males \& } \\
66 \text { females }\end{array}$ & $\begin{array}{l}3 \text { years } \\
3.5 \text { years } \\
4 \text { animals under sex months }\end{array}$ \\
\hline Total & 259 & $\begin{array}{l}159 \text { males \& } \\
100 \text { female }\end{array}$ & $\begin{array}{l}3 \text { years } \\
3.5 \text { years } \\
4 \text { animals under sex months }\end{array}$ \\
\hline
\end{tabular}

\section{2 - Virus isolation and identification:}

Buffy coat were collected from feverish animals and inoculated into MDBK cell line in which the monlayer cell culture were grown on Eagl s MEM supplemented with $3 \%$ newborn calf serum. After 48 hours positive samples showed cytopathogenic effect in the cell line that begins with cell rounding that advances to for grape-like structures, beside the formation of synthetial cell (Giant cells).

For confirmation of the specificity of CPE, specific antiserum to BHV-1 (Kindly Supplied by Institute of Virology, Hannover Veterinary School, Germany) was added to the buffy coats and incubated for 30 minutes at $37^{\circ} \mathrm{C}$ before inoculation to the cell culture. Colorado strain of BHV-1 kindly supplied by Institute of Virology, Hannover Veterinary School, Germany was used as positive control. The CPE were inhibited in both positive samples and the positive control.

\section{3 - Sero-conversion:}

Antibodies to BHV-1 were detected in the sera of convalescent animals using a commercial ELISA kits produced by Institute Pourquier, France.

\section{RESULTS and DISCUSSION}

Bovine herpesvirus 1 (BoHV-1), is a pathogen of cattle associated with two major syndromes, called infectious bovine rhinotracheitis (IBR) and infectious pustular vulvovaginitis (IPV), and a variety of clinical signs, such as conjunctivitis, encephalitis and abortions (Pastoret et al., 1982). IBR is a disease of major economic concern in many parts of the world band especially in Europe, both in countries where this infection has been eradicated and in those where the control of IBR is currently or will be 
undertaken (Thiry et al., 1999). Table (3) describes the different clinical symptoms of BHV-1 infection observed in smallholder cattle in Al-Ahsa region, KSA. The table summarizes the main items of symptoms with the percentage in the clinical diseased animals. The described symptoms are quite the same that recorded by many authors (Gibbs and Rweyemamu, 1977; Millerand Van der Maaten 1986; Bryan et al., 1994; Hage et al., 1998; Radostitis et al., 2007; Muylkens et al., 2007 and Nandi et al., 2009). Table (4) illustrates the percentage of clinical disease of BHV-1 in small holder cattle in Al-Ahsa region, KSA during 3 years observation (April, 2007- April, 2010). The total number of observed cattle was 259 from which 159 females and 100 males. The clinical disease was observed in 74 (46.6\%) females and 24 (24\%) males. Serological evidence of BHV-1 infection in dairy cattle in Kingdom Saudi Arabia was recorded by Frericks et al. (1982) and (1983). The isolation of the BHV-1 from dairy cattle in Kingdom Saudi Arabia was confirmed by Hafez and Chaudry (1985). The emergence of clinical infectious bovine rhinotracheitis in the eastern region of the Kingdom Saudi Arabia was recorded for the first time by Abu-Elzein et al. (2008). They suggested that the source of the outbreak could be due to the reactivation of a latent infection. This is highly likely, as there was no recent introduction of new animals in the affected farm. On the other hand, results of the limited serological survey on the non-vaccinated, apparently healthy 14 cattle from the affected herd indicated that a high percentage $(50 \%)$ were exposed to IBR infection and that some of them gave high $\mathrm{BP}$ values which were comparable with the reference positive serum. As no cattle were recently introduced into the farm, this high seroconversion rate could most probably indicate shedding of the IBR virus by carrier cattle in the herd. The sector of smallholders in cattle breeding constitutes an important part for cattle production on both dairy and beef cattle in Kingdom Saudi Arabia. The absence of clear regulation in this sector makes difficulty in controlling infectious diseases. On the same time the economic losses (due to mortality in newborn animals, abortion and others) in this sector due to infectious diseases are really high but unfortunately not estimated. BHV-1 infection in cattle is one of the problems that threads and persist in small holder cattle causing sever economic losses and constitutes a major source of infection to industrial cattle farms. This is probably due to the absence of application of control program for infectious diseases as for example regular vaccination and isolation of infected animals.

Table 3: Different clinical symptoms observed in 98 cattle infected with BHV-1 virus. 


\begin{tabular}{|l|c|c|}
\hline \multicolumn{1}{|c|}{ Clinical symptom } & $\begin{array}{c}\text { Number } \\
\text { of animal }\end{array}$ & $\begin{array}{c}\% \text { in } \\
\text { diseased } \\
\text { animal }\end{array}$ \\
\hline 1) Fever (up to 42 ${ }^{\circ}$ c) with anorexia & 92 & $93.88 \%$ \\
\hline 2) Sever hyperemia of nasal mucous membrane & 83 & $84.69 \%$ \\
\hline 3) Serous nasal discharge from eyes and nose & 66 & $67.35 \%$ \\
\hline 4) Increased salivation & 52 & $53.06 \%$ \\
\hline $\begin{array}{l}\text { 5) Grayish foci of necrosis on the mucous membrane of the } \\
\text { nasal septum inside the external nares. }\end{array}$ & 81 & $82.65 \%$ \\
\hline 6) A drastic fall in milk yield & 20 & $20.41 \%$ \\
\hline 7) A short, explosive cough & 25 & $16.33 \%$ \\
\hline 8) Uni-or bilateral conjunctivitis & 14 & $25.51 \%$ \\
\hline 9) Erosions covered with tenacious mucous of soft palate & 28 & $28.29 \%$ \\
\hline 10) Pharyngitis with tenacious mucopurulent exudates & 18 & $18.37 \%$ \\
\hline $\begin{array}{l}\text { 11) Bronchopneumonia (loud breath sound, crackles } \\
\text { and wheezes) }\end{array}$ & 6 & $6.12 \%$ \\
\hline 12) Abortion, retention of placenta and Endometritis & 34 & $34.69 \%$ \\
\hline $\begin{array}{l}\text { 13) Necrotic lesions on the mucosa of vulva and vagina of } \\
\text { cows, penis and prepuce of bulls, they are gray } \\
\text { translucent raised foci, erode, ulcerate and become } \\
\text { confluent }\end{array}$ & & \\
\hline $\begin{array}{l}\text { 14) Obvious signs of pain (arched back holding the tail out } \\
\text { stiffly) and frequent urination }\end{array}$ & 12 & $12.24 \%$ \\
\hline
\end{tabular}

Table 4: Percentage of clinically diseased animals by BHV-1 in smallholder cattle in Al-Ahsa region, KSA.

\begin{tabular}{|c|c|c|c|c|c|}
\hline Year & $\begin{array}{c}\text { Total } \\
\text { Animal } \\
\text { examined }\end{array}$ & Sex & Age average & $\begin{array}{c}\text { Number of } \\
\text { diseased } \\
\text { animals }\end{array}$ & $\begin{array}{l}\text { Percentage of } \\
\text { clinical disease }\end{array}$ \\
\hline 2007 & 24 & $\begin{array}{l}18 \text { males \& } \\
6 \text { female }\end{array}$ & $\begin{array}{l}3 \text { years } \\
3.5 \text { years }\end{array}$ & $\begin{array}{r}16 \\
4 \\
\end{array}$ & $\begin{array}{l}88.9 \% \\
66.7 \% \\
\end{array}$ \\
\hline 2009 & 70 & $\begin{array}{l}42 \text { males \& } \\
28 \text { females }\end{array}$ & $\begin{array}{c}3 \text { years } \\
3.5 \text { years }\end{array}$ & $\begin{array}{l}25 \\
11\end{array}$ & $\begin{array}{l}59.5 \% \\
39.3 \%\end{array}$ \\
\hline 2010 & 165 & $\begin{array}{l}99 \text { males \& } \\
66 \text { females }\end{array}$ & $\begin{array}{c}3 \text { years } \\
3.5 \text { years } \\
4 \text { animals under } \\
\text { sex months }\end{array}$ & $\begin{array}{c}33 \\
9\end{array}$ & $\begin{array}{l}33.3 \% \\
13.6 \%\end{array}$ \\
\hline Total & 259 & $\begin{array}{c}159 \text { males \& } \\
100 \text { female }\end{array}$ & $\begin{array}{c}3 \text { years } \\
3.5 \text { years } \\
4 \text { animals under } \\
\text { sex months }\end{array}$ & $\begin{array}{l}74 \\
24\end{array}$ & $\begin{array}{c}46.5 \% \\
24 \%\end{array}$ \\
\hline
\end{tabular}

\section{ACKNOWLEDGEMENT}


We acknowledge the Deanship of Scientific research, King Faisal University for the support to fulfill this research work (Project Number: 5022) for the academic year 1427-1428.

\section{REFERENCES}

Abu Elzein, E.M.E.; Housawil, F.M.T.; Al-Afaleq1, A.I. and Al-Musa1, J. (2008): Emergence of Clinical Infectious Bovine Rhinotracheitis in Eastern Saudi Arabia. Revue Élev. Méd. Vét. Pays trop., 61 (1): 11-13.

Bowland, S.L. and Shewen, P.E. (2000): Bovine respiratory disease: commercial vaccines currently available in Canada, Can. Vet. J. 41: 33-48.

Bryan, L.A.; Fenton, R.A.; Misra, V. and Haines, D.M. (1994): Fatal, generalized bovine herpesvirus type-1 infection associated with a modified-live infectious bovine rhinotracheitis parainfluenza-3 vaccine administered to neonatal calves, Can. Vet. J. 35:223-228.

Edwards, S.; White, H. and Nixon, P. (1990): A study of the predominant genotypes of bovid herpesvirus 1 found in the UK, Vet. Microbiol. 22: 213-223.

Edwards, S.; Newman, R.H. and White, H. (1991): The virulence of British isolates of bovid herpesvirus 1 in relationship to viral genotype, Br. Vet. J. 147: 216-231.

Engels, M.; Steck, F. and Wyler, R. (1981): Comparison of the genomes of infectious bovine rhinotracheitis and infectious pustular vulvovaginitis virus strains by restriction endonuclease analysis, Arch. Virol. 67: 169-174.

Frericks, W.M.; Barbour, F.M.; Al-Rasheed, A. and Hafez, S.M. (1982): Infectious bovine rhinotracheitis and salmonellosis in Saudi Arabian dairy herd. In: Proc. 12th World Congress on Diseases of Cattle, Amsterdam, Netherlands, 7-10 Sept. 1981, p. 1007-1011.

Frericks, W.M.; Hafez, S.M. and Al-Rasheed, A. (1983): Serological evidence for the occurrence of IBR in Saudi Arabia. In: 6th Symp. Biol. Aspt., Jeddah, Saudi Arabia, p. 54.

Hafez, S.M. and Chaudry, R. (1985): Isolation and identification of IBR virus in Saudi Arabia. Arab Gulf J. Sci. Res., 3: 735-744.

Hage, J.J.; Schukken, Y.H.; Dijkstra, T.; Barkema, H.W.; Van Valkengoed, P.H. and Wentink, G.H. (1998): Milk production and 
reproduction during a subclinical bovine herpesvirus 1 infection on a dairy farm, Prev. Vet. Med. 34: 97-106.

Gibbs, E.P.; and Rweyemamu, M.M. (1977): Bovine herpesviruses. Part I. Bovine herpesvirus 1, Vet. Bull. 47: 317-343.

Kaashoek, M.J.; Straver, P.H.; Van, R.E.; Quak, J. and Van Oirschot, J.T. (1996): Virulence, immunogenicity and reactivation of seven bovine herpesvirus 1.1 strains: clinical and virological aspects, Vet. Rec. 139: 416-421.

Lemaire, M.; Weynants, V.; Godfroid, J.; Schynts, F.; Meyer, G.; Letesson, J.J. and Thiry, E. (2000): Effects of bovine herpesvirus type 1 infection in calves with maternal antibodies on immune response and virus latency, J. Clin. Microbiol. 38: 1885-1894.

Mechor, G.D.; Rousseaux, C.G.; Radostits, O.M.; Babiuk, L.A. and Petrie, L. (1987): Protection of newborn calves against fatal multisystemic infectious bovine rhinotracheitis by feeding colostrum from vaccinated cows, Can. J. Vet. Res. 51: 452-459.

Metzler, A.E.; Matile, H.; Gassmann, U.; Engels, M. and Wyler, R. (1985): European isolates of bovine herpesvirus 1: a comparison of restriction endonuclease sites, polypeptides, and reactivity with monoclonal antibodies, Arch. Virol. 85: 57-69.

Miller, J.M. and Van der Maaten, M.J. (1984): Reproductive tract lesions in heifers after intrauterine inoculation with infectious bovine rhinotracheitis virus, Am. J. Vet. Res. (1984) 45: 790-794.

Miller, J.M. and Van der Maaten, M.J. (1986): Experimentally induced infectious bovine rhinotracheitis virus infection during early pregnancy: effect on the bovine corpus luteum and conceptus, Am. J. Vet. Res. (1986) 47: 223-228.

Miller, J.M.; Whetstone, C.A. and Van der Maaten, M.J. (1991): Abortifacient property of bovine herpesvirus type 1 isolates that represent three subtypes determined by restriction endonuclease analysis of viral DNA, Am. J. Vet. Res. 52: 458-461.

Muylkens, B.; Thiry, J.; Kirtin, P.; Schynts, F. and Thiry, E. (2007): Bovine herpesvirus 1 infection and infectious bovine rhinotracheitis. Vet. Res. 38 (2007) 181-209 181.

Nandi, S.; Kumar, M.; Manohar, M. and Chauhan, RS. (2009): Bovine herpes virus infections in cattle. Anim Health Res Rev. Jun;10(1): 85-98.

Pastoret, P.-P.; Thiry, E.; Brochier, B. and Derboven, G. (1982): Bovid herpesvirus 1 infection of cattle: pathogenesis, latency, consequences of latency, Ann. Rech. Vét. 13: 221-235. 
Radostits, O.M.; Gay, C.C.; Hinchcliff, K.W. and Constable, P.D. (2007): Veterinary Medicine: A text book of the diseases of cattle, horses, sheep, pigs and goats. 10th ed. ELSEVIER, ISBN 13: 978070207772.

Smith, G.A.; Young, P.L. and Reed, K.C. (1995): Emergence of a new bovine herpesvirus 1 strain in Australian feedlots, Arch. Virol. 140: 599-603.

Smith, V.W.; Coakley, W. and Maker, D. (1980): Transmission of a genital isolate of bovine herpesvirus 1 to calves by the respiratory route, Aust. Vet. J. 56: 302-304.

Spilki, F.R.; Esteves, P.A.; De Lima, M.; Franco, A.C.; Chiminazzo, C.; Flores, E.F.; Weiblen, R.; Driemeier, D. and Roehe, P.M. (2004): Comparative pathogenicity of bovine herpesvirus 1 (BHV-1) subtypes 1 (BHV-1.1) and 2a (BHV-1.2a), Pesquisa Veterinaria Brasileira 24: 43-49.

Thirty, E.; Saliki, J.; Schwers, A. and Pastoret, P.P. (1985): Parturition as a stimulus of IBR virus reactivation, Vet. Rec. 116: 599-600.

Thirty, E.; Saliki, J.; Bublot, M. and Pastoret, P.P. (1987): Reactivation of infectious bovine rhinotracheitis virus by transport, Comp. Immunol.Microbiol. Infect. Dis. 10: 59-63.

Thiry, E.; Lemaire, M.; Schynts, F.; Meyer, G.; Dispas, M. and Gogev, S. (1999): Les conséquences de l'infection des bovins par le virus de la rhinotrachéite infectieuse bovine, Point Vét. 199: 279-285.

Whetstone, C.A. and Miller, J.M. (1989): Two different strains of an alphaherpesvirus can establish latency in the same tissue of the host animal: evidence from bovine herpesvirus 1, Arch. Virol. 107: $27-34$

Zajac, MP.; Ladelfa, MF.; Kotsias, F.; Muylkens, B.; Thiry, J.; Thiry, E. and Romera, SA. (2010): Biology of bovine herpesvirus 5. Vet. J. May;184(2): 138-45. 